\title{
Delayed metamorphosis in Florida hermit crabs: multiple cues and constraints (Crustacea: Decapoda: Paguridae and Diogenidae)
}

\author{
Alan W. Harvey* \\ Department of Invertebrates, American Museum of Natural History, Central Park West at 79th St., New York, New York 10024, USA
}

\begin{abstract}
: l examined the effects of food availability, shell availability and the presence of adults on survival and duration of the megalopal stage of the intertidal hermit crabs Pagurus maclaughlinae Garcia-Gómez, Paguristes tortugae Schmitt and Chbanarius vittatus (Bosc) in the laboratory. I also considered the role of substrate availability on $C$. vittatus. All species delayed metamorphosis significantly in the absence of empty shells; shells also enhanced megalopal survival in $P$. maclaughlinae and $C$. vittatus. Water that had previously housed conspecific adults significantly improved megalopal survival and shortened tıme to metamorphosis in $P$. maclaughlinae and $P$. tortugae. Shell-less megalopae of $C$. vittatus delayed metamorphosis when kept in adult-conditioned water, but metamorphosed more quickly in the presence of sediment. Food availability did not affect the duration of the megalopal stage in $P$. maclaughlinae or $P$. tortugae, whereas starved $C$. vittatus megalopae died in $8 \mathrm{~d}$ or less. Although food availability was associated with somewhat enhanced survival in $P$ tortugae, the mechanism. underlying this effect is unknown, since $P$. tortugae was not observed to feed as either megalopae or zoeae. As in other species of Pagurus, megalopae of $P$. maclaughlinae were not observed to feed, whereas zoeae and juveniles did feed. The differences and simularities in the nature and extent of the delay capabilities of $P$. maclaughlinae, $P$. tortugae and $C$. vittatus appear to reflect the interaction among various aspects of the ecology of the adults and energetic constraints on the megalopae.
\end{abstract}

KEY WORDS: Hermit crabs - Metamorphosis Settlement Gregariousness

\section{INTRODUCTION}

Larvae of many species of benthic marine invertebrates can delay settlement and metamorphosis in the absence of often highly specific external cues (Thorson 1950, Crisp 1974, Pechenik 1990). Such cues commonly include essential postlarval resources such as food items (Hadfield 1977) or substrate (Crisp 1955), but larvae often react to more indirect indicators of suitable adult habitats. For example, in many gregarious species metamorphosis can be triggered by the presence of conspecific adults (Burke 1986). Conversely, some larvae will delay settlement and metamorphosis if they detect the presence of certain predators or competitors, even conspecific adults (Young \& Chia 1981, Durante 1991). The ability to delay meta-

•E-mail: aharvey@amnh.org morphosis varies by several orders of magnitude among marine invertebrates (Pechenik 1990). Various selective pressures (Jackson \& Strathmann 1981, Pechenik 1984, Harvey \& Colasurdo 1993) and constraints (Strathmann 1985. Woollacott et al. 1989) have been invoked to explain this variation in delay capabilities.

Hermit crabs are anomuran crustaceans well known for their dependence as adults on empty gastropod shells, which are used as shelters. Many species of hermit crabs are gregarious, particularly small intertidal species (MacKay 1945, Hazlett 1966, SnyderConn 1980, Gherardi \& Vannini 1989), Larval development in hermit crabs, as in other decapods, consists of one to several planktonic, free-swimming zoeal stages followed by a metamorphosis to a single megalopal stage, which in turn metamorphoses to the first-crab stage (Gurney 1942, Williamson 1982). The megalopa 
is the first stage capable of recognizing and using empty snail shells (Thompson 1903, Hazlett \& Provenzano 1965, Harvey 1992a). In the temperate marine family Paguridae, megalopae do not feed and, in the few species studied, delay metamorphosis at most only slightly in the absence of shells (Roberts 1971, Dawirs 1981, Harvey \& Colasurdo 1993). Megalopae are known to feed in the more tropical families Diogenidae and Coenobitidae; megalopae in the diogenid genus Clibanarius can delay metamorphosis in the absence of empty shells (Harms 1992, Harvey 1992a), whereas coenobitid megalopae will not metamorphose until they have crawled out of the water (Reese 1968, Harvey 1992b).

Most studies on settlement and metamorphosis in gregarious species have focused on either sessile (e.g. Wilson 1968, Lucas et al. 1979) or infaunal species (e.g. Rice 1986). Among motile crustaceans, metamorphosis occurs more rapidly in the presence of aduits in some species (e.g. the fiddler crab Uca pugilator: Christy 1989, O'Connor 1991; and the porcelain crabs Petrolisthes eriomerus and $P$. cinctipes: Jensen 1989, 1991), but not others (e.g. the sand crab Emerita talpoida: Harvey 1993). The sensitivity of megalopae to the presence of conspecific adults has not yet been considered for any hermit crab species. In this study I tested the hypothesis that megalopae in 3 species of hermit crabs [the gregarious pagurid Pagurus maclaughlinae Garcia-Gómez, the gregarious diogenid Paguristes tortugae Schmitt, and the nongregarious Clibanarius vittatus (Bosc)] would delay metamorphosis in the absence of potential metamorphosis-inducing cues, namely conspecific adults and empty snail shells. Because nonfeeding megalopae have been reported in pagurids but not in diogenids, I tested whether food availability affected megalopal survival or duration. However, because I had determined in a pilot study the previous year that starved $C$. vittatus megalopae could not metamorphose, I replaced food availability with substrate availability as an experimental variable for this species. I also conducted a second experiment on $P$. tortugae to test whether megalopae of this species respond differently to conspecific adults than to adults of other species of anomuran crustaceans.

\section{MATERIALS AND METHODS}

I collected ovigerous Pagurus maclaughlinae from the Indian River Lagoon north of the Link Port canal, $9 \mathrm{~km}$ north of the Fort Pierce Inlet, Florida, USA, on 25 August 1991, a single ovigerous Clibanarius vittatus from the east end of the North Beach Bridge, Fort Pierce, on 22 June 1992, and ovigerous Paguristes tortugae from Missouri Key, Florida Keys, on 8 July 1992
For $P$. maclaughlinae and $P$. tortugae, several females were required to produce the desired sample size of 144 megalopae per species. Females were housed in 51 glass jars with aerated sea water and fed bits of fish or shrimp every other day. Zoeae were individually housed in compartmented plastic boxes, containing approximately $20 \mathrm{ml}$ water per compartment, in a controlled temperature unit at $27 \pm 2^{\circ} \mathrm{C}$, with a $12: 12 \mathrm{~h}$ light:dark cycle. Zoeae were provided with clean sea water daily, and fed newly hatched Artemia nauplii, except for P. tortugae, whose zoeae do not feed (Harvey unpubl. data).

Expt 1. Megalopae were individually housed in the same sized compartmented plastic boxes as were zoeae. To determine the separate and combined effects of the presence or absence of adults, empty snail shells and food (or sediment) on the survival (i.e. successful metamorphosis to first crab) and duration of the megalopal stage, ì randomly assigned each individual after the molt to megalopa to one of 8 experimental treatments (see Table 1). Megalopae in the fed treatments were provided with newly hatched Artemia nauplii every day. Megalopae in the shell treatments were provided 3 small cerithiid shells. Megalopae in the adult-conditioned water treatments were kept in sea water that had previously contained adults ( 1 adult $\mathrm{l}^{-1}$ ) for the preceding $24 \mathrm{~h}$. Clibanarius vittatus megalopae in the sediment treatment were provided with $\sim 1 \mathrm{mi}$ of sediment (sifted through a $0.25 \mathrm{~mm}$ mesh screen to remove other macrofauna) from the beach where the female was collected. Every day all megalopae received new water, and food if appropriate, and were checked for molts or deaths.

Expt 2. To test the specificity of megalopal responses to adult-conditioned water, I conducted a second experiment using additional Paguristes tortugae megalopae (a shortage of ovigerous females prevented me from similarly testing the other species). Megalopae in this experiment were exposed to either clean sea water or water that had previously contained adults of 1 of 4 species of anomuran crustaceans. Adults were either conspecific $P$. tortugae, congeneric $P$. invisisacculus, the diogenid hermit crab Clibanarius antillensis, or the sand crab Emerita talpoida. These species are common inhabitants of shallow waters in south Florida and thus could conceivably be encountered by settling $P$. tortugae megalopae in the field. Megalopae were not given food or shells, but water was changed and data on molts and deaths recorded each day as in the first experiment.

Statistical analyses. The 2 dependent variables in this study were megalopal survival and duration (time to metamorphosis). Survival is considered to be a nominal variable with 2 possible values ('survived to metamorphosis' and 'died before metamorphosis'), and thus sur- 
vival-based hypotheses were tested using log-likelihood analysis, with $\mathrm{G}^{2}$ as the test statistic (SAS Institute 1994). The effects of the presence or absence of food, shells and conspecific adults on megalopal duration were analyzed with a 3 -way analysis of variance. In addition, I used the Tukey-Kramer HSD test to compare the effect on Paguristes tortugae megalopal duration of water conditioned by the various species in Expt 2.

\section{RESULTS}

\section{Expt 1}

Pagurus maclaughlinae larvae passed through 4 feeding zoeal stages, molting to megalopae 7 to $10 \mathrm{~d}$ after hatching. Over $80 \%(114 / 142$; Table 1$)$ of $P$. maclaughlinae megalopae successfully metamorphosed to first crab after 2 to $7 \mathrm{~d}$ (mean duration $\pm \mathrm{SD}: 3.87 \pm$ $1.00 \mathrm{~d}$; Fig. 1). Both adult-conditioned water and empty shells significantly increased megalopal survival probabilities (Table 2). However, as in other species in the genus, $P$. maclaughlinae megalopae were not observed to feed, and food availability did not affect the probability that megalopae would survive to first-crab stage (Table 2). Similarly, both shells and adult-conditioned water significantly reduced the length of the megalopal stage, whereas food availability had no such effect (Fig. 1).

Unlike Pagurus maclaughlinae, the larvae of Paguristes tortugae pass through a single, nonfeeding zoeal stage that normally lasts only $1 \mathrm{~d}$. Over $83 \%$ (118/142) of the megalopae survived to the first-crab stage (Table 1), metamorphosing in 4 to $8 \mathrm{~d}$ (mean $5.51 \pm 0.89$ d; Fig. 2). As in P. maclaughlinae, adultconditioned water led to a significant increase in
Table 2. Pagurus maclaughlinae. Results of analysis of loglikelihood comparing effects of adult-conditioned water, shells and food on megalopal survival. Wald $\chi^{2}$ is an approximate test of significance of individual effects in log-likelihood models (SAS Institute 1994)

\begin{tabular}{|lrccc|}
\hline Source & df & Log-likelıhood & \multicolumn{1}{c|}{$\chi^{2}$} & $\mathrm{p}$ \\
\hline Model & 3 & 7.04 & & \\
Error & 138 & 63.46 & & \\
Total & 141 & 70.50 & 14.08 & $<0.01$ \\
Effect test & df & Wald $\chi^{2}$ & $p$ & \\
\hline Water & 1 & 4.73 & 0.03 & \\
Shell & 1 & 8.42 & $<0.01$ & \\
Food & 1 & $<0.01$ & 0.94 & \\
\hline
\end{tabular}

megalopal survival. However, unlike P. maclaughlinae, the presence of food significantly reduced megalopal mortality, whereas shells had no significant effect (Tables 1 \& 3). As in P. maclaughlinae, both adult-conditioned water and shell availability significantly shortened the stage length, whereas food had no effect (Fig. 2).

Clibanarius vittatus passed through 4 or 5 feeding zoeal stages, becoming megalopae 23 to $33 \mathrm{~d}$ after hatching. Less than a third (47/144) of the megalopae survived to the first-crab stage, metamorphosing in 12 to $35 \mathrm{~d}$ (mean duration $19.63 \pm 7.34 \mathrm{~d}$; Fig. 3). In an earlier preliminary study, starved megalopae failed to survive more than $8 \mathrm{~d}$. In the present study, empty shells significantly increased megalopal survival probabilities, but sediment and adult-conditioned water had no effect on survival (Table 4).

Megalopal duration in Clibanarius vittatus was more complexly sensitive to external cues than in either Pagurus maclaughlinae or Paguristes tortugae. Only shell availability exerted a significant direct effect on megalopal stage duration, reducing the mean duration by almost $10 \mathrm{~d}$, although megalopae kept in sediment metamorphosed on average a near-significant $3 \mathrm{~d}$ faster than sediment-less megalopae (Fig. 3). In addition, significant interaction effects were observed between shell and sediment availability, and between shell availability and adult-conditioned water. In the first case, sediment did not affect time to metamorphosis for megalopae with shells, but significantly shortened time to metamorphosis for shell-less megalopae (Fig. 4A). In the second case, adult-conditioned water showed a near-significant tendency 

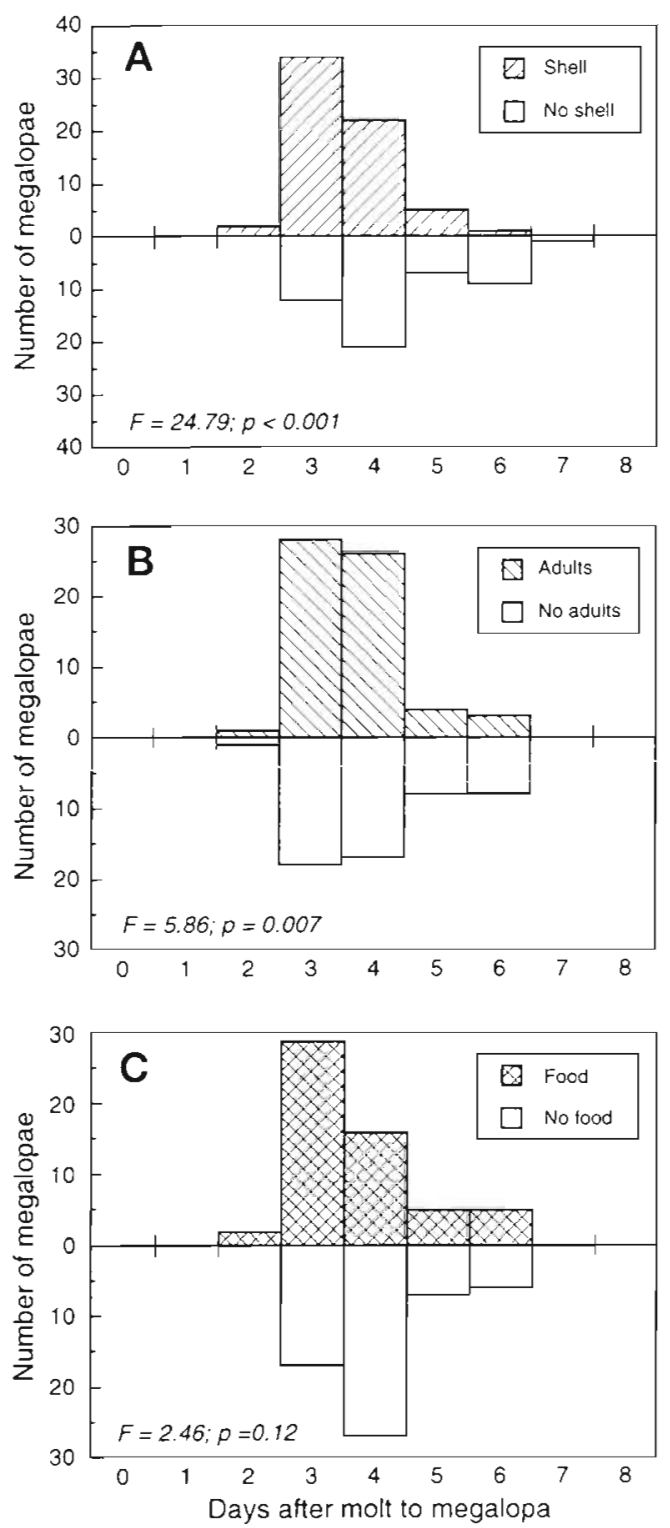

Fig. 1. Pagurus maclaughlinae. Time to metamorphosis to first crab in megalopae as a function of (A) availability of shells, (B) adult-conditioned water and (C) food

to shorten the time to metamorphosis for shelled megalopae, but significantly increased time to metamorphosis in shell-less megalopae (Fig. 4B).

Finally, for Clibanarius vittatus there were conspicuous interaction effects among all 3 variables taken together that just missed statistical significance $(p=$ $0.055)$ despite the handicap of dividing only 47 specimens among 8 treatments (Table 5). Three of four shelled treatments metamorphosed 11 to $15 \mathrm{~d}$ faster than their shell-less counterparts; surprisingly, however, there was no difference between shelled and shell-less megalopae reared with sediment and without adults (Table 5). The 4 shelled treatments did not
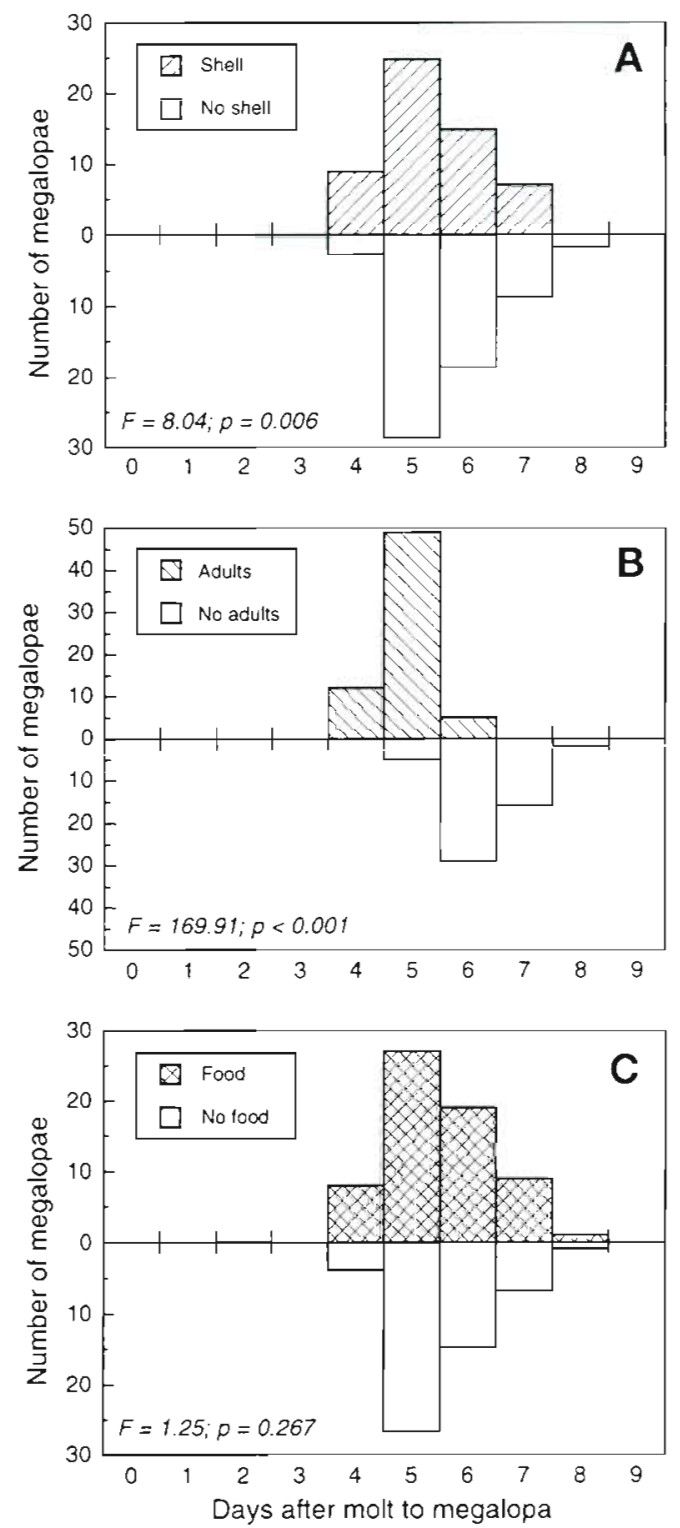

Fig. 2. Paguristes tortugae. Time to metamorphosis to first crab in megalopae as a function of (A) availability of shells, $(B)$ adultconditioned water and (C) food

differ significantly amongst themselves (i.e. no combination of sediment and adults significantly affected time to metamorphosis in shelled megalopae) (Table 5). For shell-less megalopae, the (sediment, no adult) treatment required at least 10 fewer days than the other 3 combinations, which did not significantly differ amongst themselves (Table 5).

\section{Expt 2}

Survival probabilities were significantly higher, and stage durations significantly shorter, for Paguristes tor- 
Table 3 Paguristes tortugae. Results of analysis of log-likelihood comparing effects of adult-conditioned water, shells and food on megalopal survival

\begin{tabular}{|lrccc|}
\hline Source & df & Log-likelihood & $\chi^{2}$ & $p$ \\
\hline Model & 3 & 10.49 & & \\
Error & 138 & 54.02 & & \\
Total & 141 & 64.51 & 20.98 & $\leqslant 0.01$ \\
Effect test & df & Wald $\chi^{2}$ & $p$ & \\
\hline Water & 1 & 10.79 & $<0.01$ & \\
Shell & 1 & 2.01 & 0.16 & \\
Food & 1 & 5.25 & 0.02 & \\
\hline
\end{tabular}
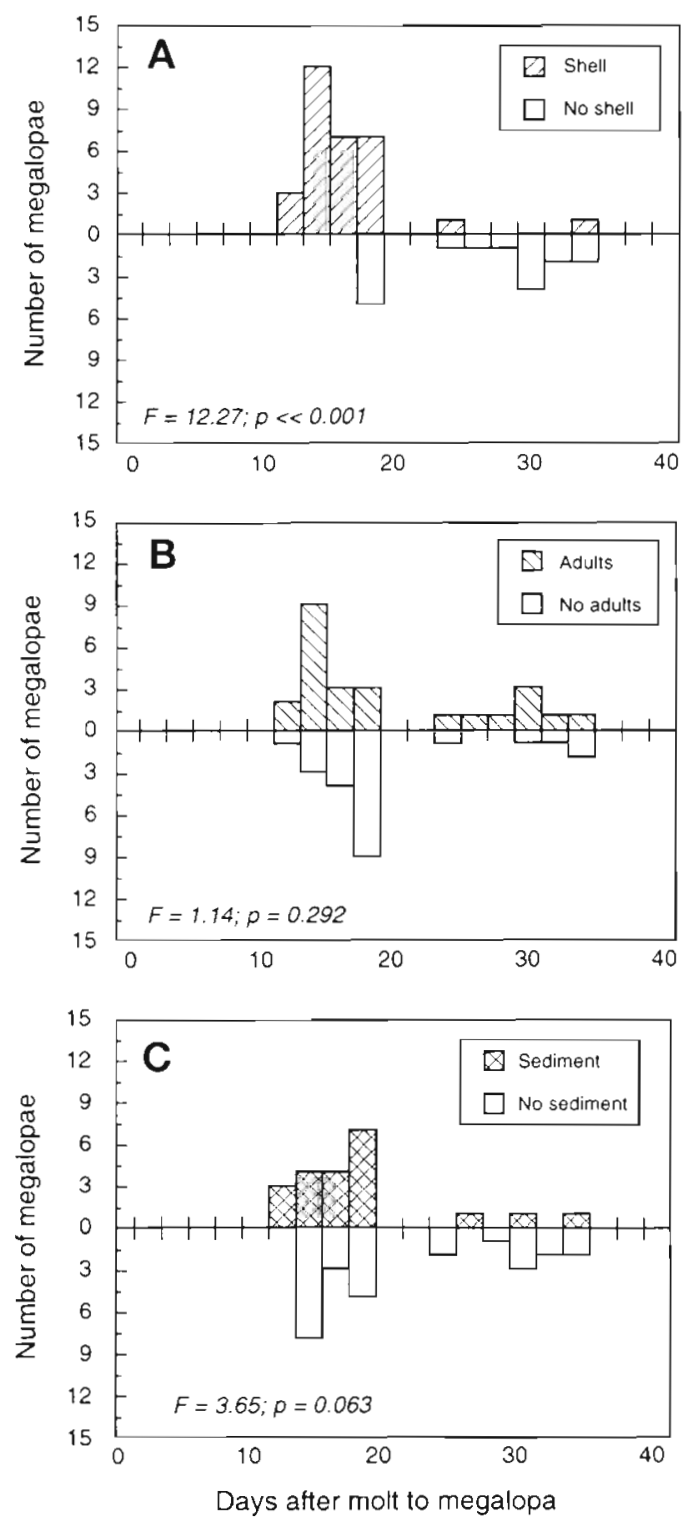

Fig. 3. Chbanarius vittatus. Time to metamorphosis to first crab in megalopae as a function of (A) availability of shells,

(B) adult-conditioned water and (C) sediment
Table 4. Clibanarus vittatus. Results of analysis of loglikelihood comparing effects of adult-conditioned water, shells and sediment on megalopal survival

\begin{tabular}{|lrccc|}
\hline Source & df & Log-likelihood & $\chi^{2}$ & $p$ \\
\hline Model & 3 & 3.61 & & \\
Error & 140 & 87.34 & & \\
Total & 14.3 & 90.95 & 7.22 & 0.06 \\
Effect test & df & Wald $\chi^{2}$ & $p$ & \\
\hline Water & 1 & 0.38 & 0.54 & \\
Shell & 1 & 5.90 & 0.02 & \\
Sediment & 1 & 0.82 & 0.36 & \\
\hline
\end{tabular}

tugae megalopae kept in adult-conditioned water of conspecifics than in either clean sea water or adultconditioned water of other species (Table 6). Megalopal survival and duration did not differ among water conditioned by $P$. invisisacculus, Clibanarius antillensis or Emerita talpoida, nor did survival or duration differ between the heterospecific and the clean sea water treatments (Table 6).
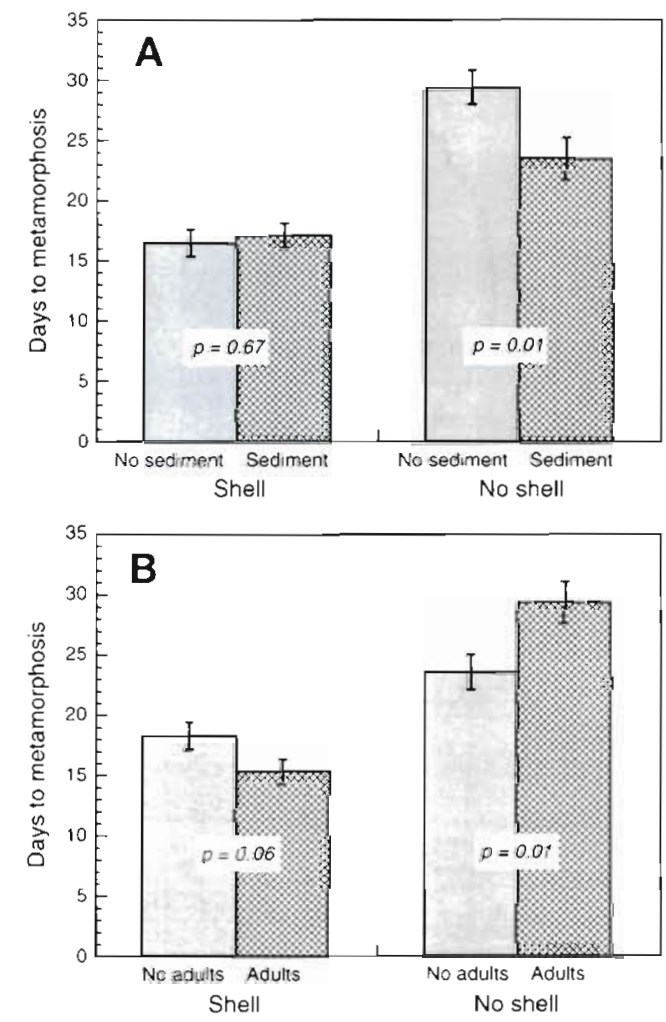

Fig. 4. Clibanarius vittatus. Interaction effects of shell availability and (A) sediment availability and (B) adult-conditioned water on time to metamorphosis to first crab in megalopae. Probabilities are contrasts extracted from the full factorial model 
Table 5. Clibanarius vittatus. Effects of potential metamorphic cues on time to metamorphosis. Treatment effects as in Table 1. +1-: treatment variable present/absent. Letters define statıstıcally significant groups

\begin{tabular}{|cccccccc|}
\hline \multirow{2}{*}{$\begin{array}{c}\text { Treat- } \\
\text { ments }\end{array}$} & Shells & \multirow{2}{*}{ Sediment } & Adults & \multicolumn{3}{c}{ Time to metamorphosis (d) } \\
\hline 1 & & & & Mean & SD & $\mathrm{N}$ \\
2 & + & + & + & $15.00 \mathrm{a}$ & 1.48 & 8 \\
3 & + & + & - & $19.14 \mathrm{a}$ & 1.58 & 7 \\
4 & + & - & + & $15.56 \mathrm{a}$ & 1.39 & 9 \\
& + & - & - & $17.29 \mathrm{a}$ & 1.58 & 7 \\
5 & - & + & + & $28.50 \mathrm{~b}$ & 2.95 & 2 \\
6 & - & + & - & $18.50 \mathrm{a}$ & 2.09 & 4 \\
7 & - & - & + & $30.17 \mathrm{~b}$ & 1.70 & 6 \\
8 & - & - & - & $28.50 \mathrm{~b}$ & 2.09 & 4 \\
\hline
\end{tabular}

Table 6. Paguristes tortugae. Effect of adult-conditioned water from different species on megalopal survival and duration. Letters define statistically significant groups

\begin{tabular}{|lccc|}
\hline Adult species & Survival (\%) & Duration (d) & $\mathrm{N}$ \\
\hline P. tortugae & $94.1 \mathrm{a}$ & $5.06 \pm 0.18 \mathrm{a}$ & 17 \\
P. invisisacculus & $44.4 \mathrm{~b}$ & $5.88 \pm 0.26 \mathrm{~b}$ & 18 \\
Clibanarius antillensis & $50.0 \mathrm{~b}$ & $6.00 \pm 0.25 \mathrm{~b}$ & 18 \\
Emerita analoga & $72.2 \mathrm{~b}$ & $6.08 \pm 0.20 \mathrm{~b}$ & 18 \\
Clean sea water (control) & $66.7 \mathrm{~b}$ & $6.63 \pm 0.26 \mathrm{~b}$ & 12 \\
\hline
\end{tabular}

\section{DISCUSSION}

Megalopae of Pagurus maclaughlinae, Paguristes tortugae and Clibanarius vittatus metamorphose more quickly when provided with empty shells. In addition, chemical cues associated with the local presence of conspecific adults shortened the time to metamorphosis in both $P$. maclaughlinae and $P$. tortugae, but inhibited metamorphosis in C. vittatus megalopae that lacked shells. Shell-less C. vittatus megalopae also metamorphosed more quickly in the presence of sediment. These cues are clearly relevant to the postlarval ecology of these species.

\section{Shells}

Megalopae of all 3 species would respond to a shell only after physically contacting it with their anterior walking legs, which are normally held directly forward in swimming megalopae. These observations are consistent with studies on other hermit crabs (Reese 1962, Hazlett \& Provenzano 1965, Harvey \& Colasurdo 1993), and suggest that initial shell recognition in naive hermit crab megalopae depends on adsorbed chemical or tactile cues rather than soluble chemical or visual cues. Adult hermit crabs have a broader repertoire, and can recognize shells using tactile, visual and soluble chemical cues, which may come from either the shell or tissue of the mollusc, and may well use adsorbed chemical cues as well (Oriheula et al. 1992, Rittschof et al. 1992). Shell-related behaviors can even be triggered in adults by chemicals released by injured hermit crabs (Rittschof et al. 1992) At present, the role of learning in this development of cue sensitivity is unknown, although it has been shown that shell preferences in Pagurus bernhardus (L.) are modifiable by previous experience (Elwood et al. 1979).

In typical hermit crab fashion, adults of all 3 species require shells. The benefits of empty shells to the survival, growth and reproductive success of postlarval hermit crabs have been well documented (Markham 1968, Fotheringham 1976, Bcrtness 1981a, b, c, Hazlett 1981). The overwhelming importance of this resource to postlarval hermit crabs makes clear the benefits of delaying metamorphosis until a suitable shell is located. Hermit crab megalopae are powerful swimmers, whereas juveniles cannot swim. Thus, a shell-less megalopa is much more motile, and presumably both less vulnerable to predation and environmental stresses and better able to search for shells, than a shell-less juvenile.

\section{Conspecific adults}

The fact that development in all 3 species was influenced by water that had previously housed adults indicates that megalopae are sensitive to soluble chemical cues. Furthermore, Paguristes tortugae megalopae (the only species so tested) showed considerable specificity, responding only to conspecific adults. This chemical receptivity of larval stages to adult stages has not been reported previously in decapods, but as noted above the behavior of adult hermit crabs has been shown to be similarly influenced by soluble chemical cues, for example, to locate potential shells at snail predation sites (Rittschof et al. 1992). This response can show considerable specificity in adults as well, as hermit crabs tend to react only to particular favored snail species, and are more likely to respond to chemicals released from conspecific adults (Rittschof et al. 1992). In Clibanarius vittatus, the chemical detected by adults originated from the hemolymph of crushed conspecifics (Rittschof et al. 1992). Thus, it is probably not the same chemical detected by the larval stages in the present study, in which conspecific adults were not damaged or stressed to obtain conditioned water. 
Although not previously studied in hermit crabs, the presence of conspecific adults has been implicated as a primary settlement cue in a variety of marine invertebrates, primarily sessile forms (e.g. Crisp 1974, Burke 1986). Given that larvae are physiologically capable of recognizing conspecifics, there are several reasons why they might benefit from responding to the local presence of adults. First, adults might provide some direct benefit to newly settled juveniles. The sand dollar Dendraster excentricus exemplifies a species in which the presence of adults directly benefits new recruits: the gregarious adults occur in dense beds that exclude tanaids, which feed on newly settled sand dollar larvae (Highsmith 1982). Adults of nongregarious species may also provide direct benefits to newly settled larvae. For example, in the porcelain crabs Petrolisthes eriomerus and $P$. cinctipes, megalopae and small juveniles gain protection from small fish predators by hiding under adults, which do not otherwise tolerate the presence of older conspecifics (Jensen 1989).

At present, there is no evidence to support the hypothesis that adult hermit crabs actively and directly benefit juveniles. Indeed, the reluctance of shell-less Clibanarius vittatus megalopae to metamorphose in the presence of conspecific adults suggests that under certain circumstances adults might be detrimental to megalopae or juveniles. Larvae of sessile barnacles (Moyse \& Hui 1981), spionid polychaetes (Levin 1981) and solitary tunicates (Durante 1991) are known to avoid settling near conspecific adults due to risks of overgrowth or predation by adults. C. vittatus adults feed primarily on detritus and are unlikely to be serious predators of megalopae or juveniles (Caine 1975, Lowery \& Nelson 1988). However, their primary mode of feeding involves sifting through the substrate with the anterior walking legs; 'such movements cause a mixing of the substratum, bringing organically rich layers to the surface' (Caine 1975, p 293). This disruptive feeding style, combined with the large size of adult C. vittatus, could pose serious physical hazards for settled megalopae or juveniles that do not enjoy the protection of a shell. Thus, it seems possible that the additional delay in metamorphosis in shell-less $C$. vittatus megalopae may be an evolutionary response to the risks posed by adults to unprotected megalopae or juveniles.

This hypothesis is supported by cage experiments in which adult Clibanarius vittatus caused significant decreases in populations of a wide variety of small benthic invertebrates, including amphipods, isopods, tanaids, polychaetes and nemerteans (Lowery \& Nelson 1988). Lowery \& Nelson suggested that $C$. vittatus negatively impacted these organisms through disturbance rather than predation. Furthermore, small shelled invertebrates, such as gastropods, bivalves and cladocerans, were not adversely affected by $C$. vittatus (Lowery \& Nelson 1988).

Larvae may also benefit from responding to conspecific adults in the absence of direct interactions between adults and larvae. For example, the local presence of adults might simply indicate that the megalopa has located a habitat suitable for settlement, assuming of course that juveniles and adults prefer similar habitats. If this is not the case (e.g Panulirus argus; Butler \& Herrnkind 1991), the local presence of adults might actually serve to indicate an inappropriate habitat for settlement. Alternatively, the species might be gregarious as adults, in which case adults might help define, not merely indicate, suitable habitat.

These hypotheses are not mutually exclusive, and indeed may be difficult to distinguish, particularly for sessile species. Even in motile species, larvae would be most likely to use adults as habitat indicators when adults are locally abundant, a condition most easily satisfied in gregarious species. For example, the fiddler crab $U_{c a}$ pugilator, in which metamorphosis is delayed in the absence of both sand and conspecific adults (O'Connor 1991), is both gregarious and usually abundant where it occurs (Williams 1984).

Although many species of hermit crab show pronounced gregarious behavior, the adaptive significance of gregariousness in hermit crabs has proved more elusive than that of shell use (Snyder-Conn 1981, Chase et al. 1988, Gherardi \& Vannini 1993). For example, Reese (1969) suggested that aggregations by intertidal hermit crabs could reduce desiccation, but hermit crabs often show intense aggregating behavior during nondesiccating conditions, or, conversely, form aggregations in exposed sites that exacerbate rates of evaporation (e.g. Gherardi \& Vannini 1993). Gherardi \& Vannini (1993) suggested that hermit crabs aggregate to facilitate shell exchanges. However, available evidence indicates that crabs in good quality shells avoid aggregations, and that aggregations tend to sort closely by size (Hazlett 1966, Snyder-Conn 1980, Gherardi \& Vannini 1993). Thus, crabs in an aggregation tend to be similar-sized and in poor quality shells, a situation that would seem to provide minimal opportunities for shell upgrades, except in the ephemeral clusters formed at predation sites (Chase et al. 1988, Rittschof et al. 1992).

In the present study, both Pagurus maclaughlinae and Paguristes tortugae are gregarious as adults, the former occurring in high densities particularly in seagrass beds (Tunberg et al. 1994), the latter forming clusters in rocky intertidal regions (Harvey pers. obs.). In contrast, adult Clibanarius vittatus do not form the dense clusters typical of several other species in the 
genus (Hazlett 1966, Snyder-Conn 1981, Gherardi \& Vannini 1993), although they can occur in high densities in suitable habitat (Lowery \& Nelson 1988). Although shell-less $C$. vittatus megalopae delayed metamorphosis in the presence of conspecifics, shelled megalopae metamorphosed almost $3 \mathrm{~d}$ more quickly in the presence of conspecifics (Fig. 4B). This suggests that hermit crab megalopae may use adults as habitat indicators even in nongregarious species. One way to better separate the influence of adults as habitatdefiners as opposed to habitat-indicators is to compare closely related species that differ in their tendencies towards gregariousness. Hermit crabs in the genera Pagurus, Paguristes and Clibanarius are excellent candidates for such a test, as each genus includes numerous gregarious and solitary species (Harvey unpubl. data)

\section{Substrate}

The influence of substrate on megalopal development was studied only in Clibanarius vittatus. The sediment used in this study came from the same site from which the adult female $C$. vittatus were collected, but there are several reasons to doubt that megalopae were using the sediment as an indicator of appropriate habitat. Although adult $C$. vittatus are especially common in fine mud habitats, they can be found in a variety of other habitats, including seagrass beds, coarser sand, oyster rubble and rock jetties (Pearse et al. 1942, Whitten et al. 1950, Lowery \& Nelson 1988). The presence of sediment significantly reduced development times only for shell-less $C$. vittatus. These were observed to eventually stop swimming and partially bury themselves in the mud, a behavior that was not observed in shelled megalopae. This suggests that shell-less $C$. vittatus megalopae may derive some measure of protection from burying in mud.

Indeed, in the absence of adults, shell-less megalopae metamorphosed as quickly as shelled megalopae. In the presence of adults, or when megalopae had shells, however, sediment did not influence megalopal development. Because shells offer protection, and adults confer risks that burying in sediment would not reduce, it would appear that sediment affects Clibanarius vittatus development times only when both protection and risks are low. This strongly implies that sediment exerts its influence on megalopae as a secondary protective agent rather than a habitat indicator (Mortensen 1921, Harvey 1993), adsorptive agent for chemical inducers of metamorphosis (Crisp \& Meadows 1963) or source of food (Gray 1974, Rice 1986).

\section{Larval feeding}

The influence of both shells and conspecific adults on megalopal duration in Pagurus maclaughlinae and Paguristes tortugae is consistent with the importance of shells to, and the gregarious nature of, their postlarval stages. However, it is important to realize that this influence was relatively limited: megalopae exposed to both shells and adults metamorphosed more quickly than megalopae with neither by an average of $31 \mathrm{~h}$ in $P$. maclaughlinae and $43 \mathrm{~h}$ in $P$. tortugae. These delay capabilities, in absolute terms, are shorter than those of nearly $90 \%$ of the 80 taxa listed by Pechenik (1990: Table 1). In contrast, Clibanarius vittatus megalopae under optimal conditions metamorphosed more quickly than megalopae with no cues by an average of $364 \mathrm{~h}$, which is longer than exactly half of the taxa listed in Pechenik (1990).

One possible explanation for this variable response to useful cues is that the ability of megalopae to delay metamorphosis is sometimes constrained, regardless of the importance of the cue (Harvey \& Colasurdo 1993). For example, the fact that megalopae in Pagurus maclaughlinae and both zoeae and megalopae in Paguristes tortugae do not feed sets an absolute limit on the amount of energy available for maintenance activities during periods of delay (Dawirs 1981, Woollacott et al. 1989)

A nonfeeding megalopal stage (termed 'secondary lecithotrophy' by Anger 1989) occurs in several other species of Pagurus (Coffin 1958, Bookhout 1972, Dawirs 1981, Harvey \& Colasurdo 1993). All Pagurus species that have been tested either do not delay metamorphosis in the absence of shells or delay only slightly (Roberts 1971, Dawirs 1981, Harvey \& Colasurdo 1993, present study).

Paguristes tortugae is the first species of coenobitoidean hermit crab reported to have nonfeeding megalopae, although most larval rearing studies on decapods simply assume all stages feed. Megalopae are known to feed in the diogenid genera Clibanarius (Harms 1992, Harvey 1992a, unpubl. data) and Calcinus (Harvey unpubl. data), and the coenobitid Birgus latro (Reese \& Kinzie 1968) and Coenobita (Nakasone 1988. Harvey 1992b). As did Clibanarius vittatus in the present study, megalopae in these genera delay metamorphosis, often for weeks, in the absence of appropriate settlement cues.

Among hermit crabs, nonfeeding zoeae (primary lecithotrophy) have been reported previously in several species of Paguristes (Hart 1937, Pike \& Williamson 1960, Rice \& Provenzano 1963), the land hermit crab Coenobita variabilis McCulloch (Harvey 1992b), and the pagurid Lithopagurus yucatanicus Provenzano (Provenzano 1968). Although primary lecitho- 
trophy has numerous consequences for both parents and offspring (Strathmann 1985), there is no intrinsic reason that nonfeeding zoeae would further constrain delay capabilities in hermit crab megalopae, particularly if the megalopae themselves can feed. For example, $C$. variabilis has lecithotrophic zoeae, but the megalopae are voracious feeders and can delay metamorphosis for at least $3 \mathrm{wk}$ in the laboratory (Harvey 1992b) Even when neither zoeae nor megalopae feed, as in $P$. tortugae, primary lecithotrophy may not strongly affect delay capabilities. Lecithotrophic zoeae are significantly larger and more advanced at hatching than allied planktotrophic species, have substantial yolky energy reserves, and quickly molt to megalopa (Rabalais \& Gore 1985). Thus, the initial energy reserves of these megalopae may not necessarily be lower than those of megalopae from planktotrophic zoeae.

Thus, the limited data available for hermit crabs suggests that the metamorphic delay capabilities of megalopae are correlated with the feeding ability of megalopae, but not with the feeding ability of zoeae. However, it is not yet possible to specify whether, in an evolutionary sense, megalopae retain the ability to feed only when they need delay capabilities, or else are able to substantially delay metamorphosis only when they are able to feed.

Acknowledgements. I thank W. Wannathong for helping to care for the animals. C. J. Hurlbut, W. B. Jaeckle, and M. P. Russell provided helpful discussion and comments on an earlier draft of this manuscript. This research was supported by a Smithsonian Postdoctoral Fellowship. This paper is Contribution No. 420 from the Smithsonian Marine Station at Link Port.

\section{LITERATURE CITED}

Anger K (1989) Growth and exuvial loss during larval and early juvenile development of the hermit crab Pagurus bernhardus, reared in the laboratory. Mar Biol 103: 503-511

Bertness MD (1981a) Pattern and plasticity in tropical hermit crab growth and reproduction. Am Nat 117:754-773

Bertness MD (1981b) Predation, physical stress, and the organization of a tropical rocky intertidal hermit crab community. Ecology 62:411-425

Bertness MD (1981c) The influence of shell type on hermit crab growth and clutch size. Crustaceana 40:197-205

Bookhout CG (1972) Larval development of the hermit crab Pagurus alatus reared in the laboratory. Crustaceana 22: $215-238$

Burke RD (1986) Pheromones and the gregarious settlement of marine invertebrate larvae. Bull Mar Sci 39:323-331

Butler MJ IV, Herrnkind WF (1991) Effect of benthic microhabitat cues on the metamorphosis of pueruli of the spiny lobster Panulirus argus. J Crust Biol 11:23-28

Caine EA (1975) Feeding and masticatory structures of selected Anomura (Crustacea). J Exp Mar Biol Ecol 18:277-301
Chase ID, Weissburg M, Dewitt TH (1988) The vacancy chain process: a new mechanism of resource distribution in animals with applications to hermit crabs. Anim Behav 36:1265-1274

Christy JH (1989) Rapid development of megalopae of the fiddler crab Uca pugilator reared over sediment: implications for models of larval recruitment. Mar Ecol Prog Ser $57: 259-265$

Coffin HG (1958) The laboratory culture of Pagurus samuelis (Stimpson) (Crustacea, Decapoda). Walla Walla Coll Publ 22:1-5

Crisp DJ (1955) The behavior of barnacle cyprids in relation to water movement over a surface. J Exp Biol 32:569-590

Crisp DJ (1974) Factors influencing the settlement of marine invertebrate larvae. In: Grant PT, Mackie AM (eds) Chemoreception in marine organisms. Academic Press, New York, p 177-265

Crisp DJ, Meadows PS (1963) Adsorbed layers: the stimulus to settlement in barnacles. Proc R Soc Lond Ser B Bıl Sci 158:364 -387

Dawirs RR (1981) Elemental composition (C, N, H) and energy in the development of Pagurus bernhardus (Decapoda: Paguridae) megalopa. Mar Biol 64:117-123

Durante KM (1991) Larval behavior, settlement preference, and induction of metamorphosis in the temperate solitary ascidian Molgula citrna Alder \& Hancock. J Exp Mar Biol Ecol 145:175-187

Elwood RJ, McClean A, Webb L (1979) The development of shell preferences by the hermit crab Pagurus bernhardus. Anım Behav 27:940-946

Fotheringham N (1976) Effects of shell stress on the growth of hermit crabs. J Exp Mar Biol Ecol 23:299-305

Gherardi F, Vanninı M (1989) Field observations on activity and clustering in two intertidal hermit crabs, Clibanarius virescens and Calcinus laevimanus (Decapoda, Anomura) Mar Behav Physiol 14:145-159

Gherard F, Vannini M (1993) Hermit crabs in a mangrove swamp: proximate and ultimate factors in the clustering of Clibanarius laevimanus. J Exp Mar Biol Ecol 168:167-187

Gray JS (1974) Animal-sediment relationships. Oceanogr Mar Biol A Rev 12:223-261

Gurney R (1942) Larvae of decapod Crustacea. Ray Society, London

Hadfield MG (1977) Chemical interactions in larval settling of a marine gastropod. In: Faulkner DJ, Fenical WH (eds) Marine natural products chemistry. Plenum Press, New York, p 403-413

Harms J (1992) Larval development and delayed metamorphosis in the hermit crab Clibanarius erythropus (Latrielle) (Crustacea, Diogenidae). J Exp Mar Biol Ecol 156:151-160

Hart JFL (1937) Larval and adult stages of Britush Columbia Anomura. Can J Res, Sect D 15:179-220

Harvey AW (1992a) Costs and benefits of delayed metamorphosis in the Australian hermit crab Clibanarius longitarsus. Am Zool 32:114A.

Harvey AW (1992b) Abbrevlated larval development in the Australian terrestrial hermit crab Coenobita variabllis McCulloch (Anomura: Coenobitidae). J Crust Biol 12: $196-209$

Harvey AW (1993) Larval settlement and metamorphosis in the sand crab Emerita talpoida (Crustacea: Decapoda: Anomura). Mar Biol 117:575-581

Harvey AW, Colasurdo EA (1993) Effects of shell and food availability on metamorphosis in the hermit crabs Pagurus hirsutiusculus (Dana) and Pagurus granosimanus (Stimpson). J Exp Mar Biol Ecol 165:237-249 
Hazlett BA (1966) Social behavior of the Pagundae and Diogenidae of Curaçao. Stud Faun Curaçao 23:1-143

Hazlett BA (1981) The behavioral ecology of hermit crabs. A Rev Ecol Syst 12:1-22

Hazlett BA, Provenzano AJ Jr (1965) Development of behavior in laboratory reared hermit crabs. Bull Mar Sci 15: $617-633$

Highsmith RC (1982) lnduced settlement and metamorphosis of sand dollar (Dendraster excentricus) larvae in predation-free sites: adult sand dollar beds. Ecology 63:329-337

Jackson GA, Strathmann RR (1.981) Larval mortality from offshore mixing as a link between precompetent and competent periods of development. Am Nat 118:16-26

Jensen GC (1989) Gregarious settlement by megalopae of the porcelain crabs Petrolisthes cinctipes (Randall) and P. eriomerus Stimpson. J Exp Mar Biol Ecol 131:223-231

Jensen GC (1991) Competency, settling behavior, and postsettlement aggregation by porcelain crab megalopae (Anomura: Porcellanidae). J Exp Mar Biol Ecol 153:49-61

Levin LA (1981) Dispersion, feeding behavior and competition in two spionid polychaetes. J Mar Res 39:99-117

Lowery WA, Nelson WG (1988) Population ecology of the hermit crab Clibanarius vitiatus (Decapoda: Diogenidae) at Sebastian Inlet, Florida. J Crust Biol 8:548-556

Lucas MI, Walker G, Crisp DJ (1979) An energy budget for the free-swimming and metamorphosing larvae of Balanus balanoides (Crustacea: Cirripedia). Mar Biol 55:221-229

MacKay DCG (1945) Notes on the aggregating marine invertebrates of Hawaii. Ecology 26:205-207

Markham JC (1968) Notes on growth-patterns and shellutilization of the hermit crab Pagurus bernhardus. Ophelia 5:189-205

Mortensen T (1921) Studies on the development and larval forms of echinoderms. GE C Gad, Copenhagen

Moyse J, Hur E (1981) Avoidance by Balanus balanoides cyprids of settlement on conspecific adults. J Mar Biol Ass UK 61:449-460

Nakasone Y (1988) Larval stages of Coenobita purpureus Stimpson and C. cavipes Stimpson reared in the laboratory and survival rates and growth factors of three land hermit crab larvae (Crustacea: Anomura). Zool Sci 5:1105-1120

O'Connor NJ (1991) Flexibility in timing of the metamorphic molt by fiddler crab megalopae Uca pugilator. Mar Ecol Prog Ser 68:243-247

Orihuela B, Diaz H, Forward RBJ, Rittschof D (1992) Orientation of the hermit crab Clibanarius vittatus (Bosc) to visual cues: effects of mollusc chemical cues. J Exp Mar Biol Ecol $164: 193-208$

Pearse AS, Humm HJ, Wharton GW (1942) Ecology of sand beaches at Beaufort, North Carolina. Ecol Monogr 12: $135-190$

Pechenik JA (1984) The relationship between temperature, growth rate, and duration of planktonic life for larvae of the gastropod Crepidula fornicata (L.). J Exp Mar Bıl Ecol $74: 241-257$

Pechenik JA (1990) Delayed metamorphosis by larvae of benthic marne invertebrates: does it occur? Is there a price to pay? Ophelia 32:63-94

Pike RB, Williamson DI (1960) Larvae of decapod crustacea of the families Diogenidae and Paguridae from the Bay of Naples. Pubbl Staz Napoli 31:493-532

Provenzano AJ Jr (1968) Lithopagurus yucatanicus a new genus and species of hermit crab with a distinctive larva.

This article was presented by R. S. Scheltema, Woods Hole, Massachusetts, USA
Bull Mar Sci 18:627-644

Rabalais NN, Gore RH (1985) Abbreviated development in decapods. In: Wenner AM (ed) Crustacean issues II: Larval growth. AA Balkema, Rotterdam, p 67-126

Reese ES (1962) Shell selection behaviour of hermit crabs Anim Behav 10:347-360

Reese ES (1968) Shell use: an adaptation for emigration from the sea by the coconut crab. Science 161:385-386

Reese ES (1969) Behavioral adaptations of intertidal hermit crabs. Am Zool 9:343-355

Reese ES, Kinzie RA (1968) The larval development of the coconut or robber crab Birgus latro (L.) in the laboratory (Anomura, Paguridea). Crustaceana (Suppl) 2:117-144

Rice AL, Provenzano AJ Jr (1963) The zoeal stages and the glaucothoe of Paguristes sericeus A. Milne-Edwards (Anomura, Dlogenidae). Crustaceana 8:239-254

Rice ME (1986) Factors influencing larval metamorphosis in Golfingia misakiana (Sipuncula). Bull Mar Sci 39:362-375

Rittschof D, Tsai DW, Massey PG, Blanco L, Kueber GL Jr Haas RJ Jr (1992) Chemical mediation of behavior in hermit crabs: alarm and aggregation cues. J Chem Ecol 18:959-984

Roberts Mí Jr (1971) Larval development of Pagurus longicarpus Say reared in the laboratory. IV. Aspects of the ecology of the megalopa. Biol Bull 141:162-166

SAS Institute (1994) JMP statistics and graphics guide, version 3. SAS Institute, Inc, Cary, NC

Snyder-Conn EK (1980) Tidal clustering and dispersal of the hermit crab Clibanaruus digueti. Mar Behav Physiol 7 $135-154$

Snyder-Conn EK (1981) The significance of clustering in the hermit crab Clibanarius digueti. Mar Behav Physiol 8 $43-51$

Strathmann RR (1985) Feeding and nonfeeding larval development and life history evolution in marine invertebrates A Rev Ecol Syst 19:339-361

Thompson MT (1903) The metamorphosis of the hermit crab. Proc Boston Soc Nat Hist 31:147-209

Thorson G (1950) Reproductive and Jarval ecology of marine bottom invertebrates. Biol Rev 25:1-45

Tunberg BG, Nelson WG, Smith G (1994) Population ecology of Pagurus maclaughlinae Garcia-Gómez (Decapoda: Anomura: Paguridae) in the Indian River Lagoon, Florida. J Crust Biol 14:686-699

Whitten HL, Rosene HF, Hedgpeth JW (1950) The invertebrate fauna of Texas coast jetties; a preliminary survey Publ Inst Mar Sci, Texas 1:53-87

Williams AB (1984) Shrimps, lobsters and crabs of the Atlantic coast of the eastern United States, Maine to Florida Smithsonian Institution Press, Washington, DC

Williamson DI (1982) Larval morphology and diversity. In: Abele LG (ed) The biology of Crustacea, Vol 2, Embryology, morphology, and genetics. Academic Press, New York, p 43-110

Wilson DP (1968) The settlement behaviour of the larvae of Sabellaria alveolata (L.). J Mar Biol Ass UK 48:387-435

Woollacott RM, Pechenik JA, Imbalzano KM (1989) Effects of duration of larval swimming period on early colony deve]opment in Bugula stolonifera (Bryozoa: Chellostomata) Mar Biol 102:57-63

Young CM, Chia FS (1981) Laboratory evidence for delay of larval settlement in response to a dominant competitor. Int $\mathrm{J}$ Invert Reprod 3:221-226

Manuscript first received: April 3, 1995

Revised version accepted: March 11, 1996 